\title{
Debt-for-Nature Swaps: Environmental Colonialism or a Way Out from the Debt Crisis that Makes Sense?
}

\author{
By Hildegard Bedarff, Bernd Holznagel, and Cord Jakobeit 1
}

An often neglected side effect of the debt crisis is that it has contributed to bring the environment in many Third World debtor countries to the brink of breakdown. 2 Among other reasons, the drive to boost export earnings and raise much-needed foreign exchange in order to service, let alone pay off, the enormous sum of $\$ 1,300$ billion of total Third World debt has increased the pressure to cut down forests, shift from mixed farmlands to cash-crop monocultures, and destroy vast wetlands. The results are increasingly obvious and have only recently started to catch worldwide attention: a possible greenhouse effect for the entire globe, more frequent droughts and floods, increasing soil erosion, declining water supplies and qualities, the extinction of valuable species of plants and animals. Tropical rain forests, in particular, threaten to disappear completely within the next thirty to fifty years, if current rates of clearing are maintained. 3

In the last few years, Third World governments, in cooperation with conservation groups in the United States and Europe, have started to address some of these problems. The idea of swapping debt for equity, set forth as one of the first steps to alleviate the debt crisis, was expanded to benefit the environment. In 1984, Thomas E. Lovejoy, then vice-president for science of the World Wildlife Fund (WWF), presented the following idea: "Under the best circumstances, debtor nations find it hard to address critical conservation problems because of multiple social needs. Stimulating conservation while ameliorating debt would encourage progress on both fronts. 4 Since the initial proposal, eight debt-for-nature swaps have been arranged for a total of six countries. However, debt-for-nature swaps have also

1 Financial support from the Freie Universität Berlin for travels to Washington, D.C., is hereby gratefully acknowledged.

2 The relation between debt and environmental degradation is the starting point for almost everything that has been written about debt-for-nature swaps. Compare, e.g., SWAPS, The Newsletter of New Financial Instruments, Vol. 2, No. 11, November 1988; Helmut Schreiber, "Debt-For-Nature Swap"- An Instrument against Debt and Environmental Destruction, Institut für Europäische Umweltpolitik, January 1989, Bonn, pp. 8-10; Robert P. Ball, Debt-For-Nature Swaps: An Innovative Way to Finance Conservation, unpublished paper: Woodrow Wilson School, Princeton University, May 1989.

3 The consequences of this destruction are described in Dieter Oberndörfer, Schutz der tropischen Regenwälder durch Entschuldung, München, 1989, pp. 1-10.

4 Thomes E. Lovejoy, Aid Debtor Nation's Ecology, in: New York Times, October 4, 1984. 
drawn some criticism. The major concem in LDCs (less developed countries) is over sovereignty, because a new ecological colonial system is perceived as a possible consequence of those deals.

This paper will describe the mechanism of debt-for-nature swaps and present the most interesting cases so far, look into the detailed arrangement in the case of Costa Rica, discuss the pros and cons, and speculate on the prospects of this innovative way to finance environmental protection in the Third World. What are these swaps: a sensible way to alleviate the debt crisis while doing the threatened environment some good or just a "greenish" twist in the persisting dominance that the North is exerting over the South of this planet? Considering the European and the West German perspective, we conclude with a list of specific recommendations for policy-makers, bankers and the public alike.

\section{How Debt-for-Nature Swaps Work}

As for other ways to alleviate the debt burden, 5 the emergence, after 1982, of a secondary market for commercial debt where banks could trade and sell their foreign debt at discounted rates must be understood as a prerequisite for every debt-for-nature swap that was to follow. Secondary markets for commercial debt reflected the growing concern of many who felt that much of the accumulated debt would never be fully serviced - let alone be fully repaid - and hence was not worth its face value. 6

One of the major opportunities, provided by the secondary markets, proved to be the swap, 7 in which one financial asset is sold and another purchased, in this case at a more or less substantial discount. In its most common form, the debt-equity swap, a potential foreign investor in an LDC purchases some debt from a bank in the secondary market and takes it to the debtor's central bank. The central bank then purchases the debt in local currency under the condition that the currency be used for foreign direct investment. Therefore, debtequity swaps have become popular as many commercial banks, multinational corporations

5 Other ways are discussed in Jeffrey Sachs and Peter Huizinga, U.S. Commercial Banks and the Developing-Country Debt Crisis, Brookings Papers on Economic Activity, 2nd edition, Washington, D.C., 1987; Ball, op. cit., pp. 12-18.

6 As of February 1989, Bolivian debt was selling at between 9 and $10 \%$ of face value, Peru between 4 and $6 \%$, Brazil between 29.25 and $30 \%$, Colombia between 51 and $52 \%$. The worst cases, perceived as really bad risks, are non-surprisingly, however, Nicaragua ( 2 to $4 \%$ ) and Sudan (2 to $5 \%$ ). The sources of this information are bid and ask prices for less developed country bank loans provided by Salamon Brothers, referred by Ball, op. cit., p. 93.

7 The swap is translated by Betsy Cody, Debt-For-Nature Swaps in Developing Countries: An Overview of Recent Conservation Efforts, Congressional Research Service, The Library of Congress, September 22, Washington, D.C., 1988, p. 1, as a "Sale With A Purchase". 
and entrepreneurs have found this to be a relatively cheap way of financing new investments and reducing the exposure to dubious loans at the same time. From the LDC perspective, this transaction reduces the amount of outstanding debt on which the borrower country has to pay interest in hard currency, 8 thereby saving funds for other much-needed imports.

However, the scale of these operations has always been limited: debt-equity swaps depend on formal programs being established in a debtor country that may vary substantially from one country to the next, they potentially increase existing inflationary pressures that are associated with monetary expansion, and they increase foreign ownership of a country's most productive assets, with the foreign owners hoping to eventually take their profits out of the country. Especially the latter increases emotional and political reservations against such deals. Given these reasons, debt-equity swaps cannot be considered as a means to solve the debt crisis.

From the outset, debt-equity swaps have not been limited exclusively to the commercial sector. Non-profit organizations have successfully completed debt conversions in Bolivia, Brazil, Chile, Costa Rica, Ecuador, Mexico, Sudan, Nigeria, and the Philippines, with a lot more candidates on their lists. Also, with the relationship between the debt crisis and increased environmental degradation in mind, conservation and environmental groups have become interested once the debt crisis had intensified and the secondary market had grown. Their idea was to use the mechanism of the secondary market to acquire a portion of a country's debt sold at the discounted price by a commercial bank while, at the same time, working out mutually agreeable arrangements with local, environmental non-government organizations (NGOs) and government agencies of the LDC to trade the cancellation of the debt in return for earmarking equivalent amounts of local currency for conservation purposes. 9

8 See Barbara Bramble, How debt can be swapped for trees? National Wildlife Federation USA, Washington, D.C., May 1988, p. 2.

9 For a general discussion of the debt-for-nature swap approach, see Stein Hansen, Dept for Nature Swaps: Overview and Discussion of Key Issues, World Bank Environmental Department, Working Paper No. 1; February 1988, pp. 2-3; Bramble, op. cit., pp. 2-4; Oberndörfer, op. cit., pp. 21-24; Schreiber, op. cit.; pp. 11-15. 
Table 1: Debt-For-Nature Swaps, in US-\$, as of August 1989

\begin{tabular}{llcrrrr} 
Country & Date & Purchaser & Cost & \multicolumn{1}{l}{$\begin{array}{l}\text { Face Value } \\
\text { ofDebt }\end{array}$} & $\begin{array}{l}\text { Cost as } \\
\text { \% of } \\
\text { Face Value }\end{array}$ & \multicolumn{1}{c}{$\begin{array}{l}\text { Conservation } \\
\text { Bonds } \\
\text { Generated (1) }\end{array}$} \\
Bolivia & $7 / 87$ & CI & 100,000 & 650,000 & 15.4 & 250,000 \\
Costa Rica & $3 / 88$ & NPF/WWF/TNC & 891,000 & $5,400,000$ & 16.5 & $4,050,000$ \\
& $1 / 89$ & TNC (2) & 784,000 & $5,600,000$ & 14.0 & $1,680,000$ \\
Ecuador & $12 / 87$ & WWF & 354,000 & $1,000,000$ & 35.4 & $1,000,000$ \\
& $4 / 89$ & WWF/TNC/MBG & $1,068,750$ & $9,000,000$ & 11.9 & $9,000,000$ \\
Philippines & $1 / 89$ & WWF & 200,000 & 390,000 & 51.3 & 390,000 \\
Madagascar & $8 / 89$ & WWF & 950,000 & $2,100,000$ & 45.2 & $2,100,000$ \\
Zambia & $8 / 89$ & WWF & 470,000 & $2,270,000$ & 20.7 & $2,270,000$
\end{tabular}

(1): Does not include interest eamed over life of the bonds.

(2): Others included the WWF, the NPF, the government of Holland, the Swedish Society for the Conservation of Nature, the People's Trust for Endangered Species of the UK and several US foundations

CI: Conservation International

WWF: World Wildlife Fund

TNC: The Nature Conservancy

MBG: Missouri Botanical Gardens

NPF: National Park Foundation of Costa Rica

Sources: The Nature Conservancy, U.S. Debt-for Nature Swaps to Date, Arlington, Virginia, 1989, and our calculations.

Although debt-equity swaps are the models for debt-for-nature swaps, a number of differences have to be noted. While the primary motive of a debt-equity swap is profit, debt-for-nature swaps are supposed to benefit the debtor country through the provision of funds for conservation programs. In debt-for-nature swaps, unlike in the case of debt-equity swaps, there is no equity exchanged. The investors do not take title to any asset; the title of land is left to domestic hands. All that local NGOs are receiving is a local currency bond or an agreement that the debtor country will make local resources available for local parks, conservation, or renewable resource management programs. Also, the funds generated by a debt-for-nature swap will not leave the country.

This list of differences, among other reasons, helps to explain why no more than the existing eight swaps have been agreed upon so far. In addition to all prerequisites necessary for debt-equity swaps - notably the often time-consuming establishment of a debt-equity 
mechanism for a particular country -, debt-for-nature swaps require a lot more. ${ }^{10} \mathrm{~A}$ conservation group from the North must be interested in a specific environmental program in an LDC and have the capital (or a willing donor) to purchase the debt. The discount for the debt in the secondary market must be sufficiently high in order to provide the conservation group from the North with an incentive not to transfer its funds directly into the LDC. In the LDC, agreements have to be made with the government, the central bank, and the local conservation group about the often cumbersome details of the deal itself: exchange rate, maturation schedule, and price to pay off the debt. All this requires that within the LDC, there is a reliable conservation group that must also be accepted by the local government. Furthermore, there must be sufficient confidence in the local capacity to manage and monitor the envisaged new environmental program or plan. In order to demonstrate the wide variety of opportunities but also the difficulties that are involved, the following chapter will look into some of the existing debt-for-nature swaps and into one particularly interesting example of failure.

\section{Case Studies}

\section{Bolivia}

The first debt-for-nature swap was announced in July, 1987, and involved Conservation International, an American environmental group, and Bolivia, a country that met excellent conditions for a start.11 Bolivian debt was selling at a huge discount in secondary markets (at $15 \%$ of face value); the govemment was supportive of the plan and owned the land already; and the area chosen in Northern Bolivia was largely unexploited and promised to remain so for quite some time. Conservation International bought $\$ 650,000$ worth of Bolivia's debt from a Swiss bank for roughly $\$ 100,000$, using Citicorp Investment Bank to manage the purchase. The money was provided by the Frank Weeden Foundation of the United States, especially to "act as a catalyst"12, as Alan Weeden, president of the foundation, pointed out, and in order to demonstrate to the financial community that such deals were possible.

The Bolivian govemment issued a decree giving the highest legal protection status to nearly 4 million hectares of its forest land in the Amazon Basin; establishing a plan to manage the land, including research on various kinds of sustainable uses by local inhabitants of the

10 See for the following list Cody, op. cit., pp. 18-19.

11 For this case study, see John Walsh, Bolivia Swaps Debt for Conservation, Science, Vol. 237, August 7, 1987, pp. 596-597; World Wildlife Fund, Debt-for-Nature Swaps. A New Conservation Tool, WWF Letter, 1988, No. 1, p. 5; Schreiber, op. cit., 20-21.

12 This quote here from Ball, op. cit., p. 19. 
area; and $\$ 250,000$ worth of local currency placed in an endowment for management of the area. In return, the $\$ 650,000$ debt instrument was cancelled.13 Local participants include the Ministry of Agriculture, the Bolivian Foundation for the Conservation of Nature, and many others. Within several months, similar arrangements were announced in Costa Rica and Ecuador. 14

\section{Costa Rica}

The Costa Rican case, and all the others that have followed suit so far are, however, different from the Bolivian case. With the WWF being involved in all other swaps, the idea of simple conservation lost out to the idea of sensible management of natural resources for sustainable development by local NGOs. On the side of the WWF, there was a growing awareness that without addressing the economic problems that underlie the breakdown of the environment a long-term solution to the crisis could not be found. 15 The central feature of the two deals involving Costa Rica16 was the establishment of a long-term endowment for conservation, not another land set-aside. The deals followed the understanding that habitat conservation is not achieved by trying to lock up land but by managing natural resources for sustainable development and involving local people in conservation and development decisions. 17 The swaps are for local currency, in the form of long-term bonds, issued by the debtor government. The interest payable each quarter is used for conservation programs. Thus the debt acquired by the conservation groups from the North is turned back to be borrowers, i. e., cancelled, in return for the governments issuing an equivalent amount of long-term local currency bonds for conservation. These bonds are held, and the proceeds used, by a local conservation.

The debt-for-nature agreement dated from March 4, 1988 between the World Wildlife Fund of the United States and the Ministerio de Recursos Naturales, Energía y Minas together with the Fundación de Parques Nacionales 18 provides a good example for this

13 See Bramble, op. cit., p. 3.

14 The Ecuadorian case is described in Barbara Bramble, Deborah Burand, Randall Curtis, Diana Page, Michael Sweatman, A Brief Summary of Debt-For-Nature Swaps, Arlington, Virginia: The Nature Conservancy, August 1989; Michael Weisskopf, Ecuador Gets Aid for Debt, Environment, Washington Post, April 6, 1989.

15 In Costa Rica, e.g., the WWF helped fund a govemment and National Park Federation effort to evict and resettle gold miners from a nature reserve area. See World Wildlife Fund and the Conservation Foundation, A Quarter Century in Costa Rica: Background Paper, Washington, D.C., not dated.

16 See Ball, op. cit., pp. 19-22; Schreiber, op. cit., 21-22; World Wildlife Fund, op. cit., pp. 6-7.

17 Bramble, op. cit., p. 4.

18 The text of this debt-for-nature agreement is available from World Wildlife Fund, 1250 TwentyFourth Street, NW, Washington, D.C. 20037, USA. 
mechanism. ${ }^{19}$ The deal is part of the $\$ 5.4$ million swap of March 1988, in which WWF was one of the participants. Under section 1, WWF makes the commitment to arrange for the acquisition of public sector indebtedness of Costa Rica in an aggregate principal amount of up to $\$ 3,000,000$ of face value over a three year period. This implies that the WWF uses $\$ 495,000$ from its own funds to buy this amount of debt.20 The indebtedness will be exchanged, in accordance with all applicable requirements of Costa Rican law, into monetary stabilization bonds issued by the Central Bank of Costa Rica in Colones equivalent to not less than $75 \%$ of the aggregate principal amount of the indebtedness exchanged therefore. The bonds will be delivered to the Fundación de Parques Nacionales, which shall be entitled to receive all payments of principal land interest. Under Section 2 (a), the parties to the contract agree to use the proceeds payable on the bonds for (1) planning, administration, protection, and management of protected areas and their buffer zones; (2) acquisition of property for the purpose of wildlands protection; and (3) training a cadre of conservation professionals. The attachment to the agreement points out that the priority target areas are the Corcovado National Park, the Guanacaste National Park, the Tortuguero National Park, the Monteverde Cloud Forest and the La Amistad International Park. Future projects will be selected from time to time through an agreement by Fundación de Parques Nacionales and WWF. However, under Section 2 (c) these projects have to be compatible with the national policies of the Costa Rican government. It is worth noting that under Section 3 other NGOs committed to the goals of wise use of Costa Rica's natural resources are invited to participate in the implementation process of this agreement.

To sum up the advantages for both: In this case, the NGOs from the North spent $\$ 891,000$ to see $\$ 4,050,000$ benefiting the environment. On the top of it, the Costa Rican govemment is obliged to pay an annual $25 \%$ interest to local NGOs. Costa Rica reduces its debts by $25 \%$ and is also able to spend valuable hard currency on much-needed other imports. In the second Costa Rican deal the government reduces its debt even by $70 \% .21$

\section{Madagascar}

With the first debt-for-nature swaps agreed upon for the Philippines and Madagascar, the instrument has started to expand its use beyond the Latin American sphere. The Malagasy

19 See for further examples, World Wildlife Fund, Debt-for-Nature Agreement between WWF-U.S. and Fundación Naturaleza, Ecuador, December 14, 1987; World Wildlife Fund, Debt-for-Nature Agreement between WWF-U.S. and Department of Environment and Natural Resources of the Republic of the Philippines, and the Haribon Foundation, June 24, 1988.

20 See table 1.

21 The debt-for-nature swaps in Ecuador were the first in which the full face value of the debt will be redeemed in local currency. Now there is only the advantage of hard currency saving left. However, this change is even more beneficial for the environment. See table 1. 
swap, in particular, was important, because it started an African involvement. Although the African debt is not large enough to precipitate a world financial crisis, the continent's debt is enormous in relation to the gross national product. Therefore, the constraints on the environment are at least equally severe. Hence a lot more potential candidates are standing in line to be included in future swaps. Although most African debt (over $70 \%$ ) is owed to governments and public lending institutions, the deal with Madagascar was struck along the Latin American lines making use of private bank debt.22 Again, the swap was brought off by the American branch of the WWF which, after some years of effort, managed to persuade Madagascar to let it buy $\$ 2.1$ million of the Malagasy debt from seven private Western banks, led by Bankers Trust. 23

The new debt-for-nature swap will put more than $\$ 2$ million in local currency into 12 national parks and many small reserves, including several conservation projects and the employment of 400 park rangers. The swap was paid for by a $\$ 1$ million grant to WWF from the American government, through its Agency for International Development (AID) which had already participated in the Bolivian swap. 24

After the initial obstacles have been overcome and after the deal's detailed terms have been reshaped, it seems that the concept of debt-for-nature swaps is now prepared for progress in other countries. Deals are said to be negotiated now, among others, in Peru, Argentina, Venezuela, Mexico, Jamaica, and the Dominican Republic; in Africa, other candidates include the Ivory Coast, Nigeria, Cameroon, Zaire, Niger, and Sudan, while Indonesia would be Asia's prime target for a second swap. 25 Even some Eastern European countries

22 See World Wildlife Fund News Release, WWF \& Madagascar Announce First Debt-For-Nature Swap In Africa, Washington, D.C., August 3,1989; and The Economist, Madagascar, A Debt to nature, Vol. 312, No. 7616, August 19, 1989, p. 41.

23 Included were Germany's Dresdner Bank; AMRO Bank of the Netherlands; the French Société Générale, and Crédit Commercial de France; the Banque de l'Union Européenne; and the British National Westminster Bank.

24 In the Bolivian deal, AID contributed $\$ 150,000$ to the $\$ 250,000$ fund in local currency to manage the reserve. See Ball, op. cit., p. 18. EPD-Entwicklungspolitik, No. 9, May 1989, p. 2-3, reported that Deutsche Bank of West Gernany will donate up to $\$ 1.6$ million of Malagasy debt cancellation payments to WWF over the next 8 years to be used on WWF's conservation projects in Madagascar. The first donation of foreign debt by a bank ever occurred when the Fleet National Bank in Rhode Island, USA, gave $\$ 254,000$ of debt to the American Nature Conservancy to be used to endow a reserve in Costa Rica. See The Nature Conservancy, Background Paper Debt-ForNature Swaps, Arlington, Virginia, not dated, p. 2.

25 NGOs generally must be able to get at least double the benefits out of the swap as compared to altemative financing. Therefore, a debt selling at a higher price than $50 \%$ of face value - as is the case with much of Asian debt - is difficult to include in debt-for-nature swaps. See Ball, op. cit., pp. 43-44, and Konrad von Moltke, Debt for Nature: Current Situation and Future Prospects, paper presented at WWF N.O. Meeting, Sevilla, Spain, April 28-29, 1988, p.2. 
have been suggested, such as Poland. ${ }^{26}$ However, there have also been major setbacks, best illustrated by the case of Brazil.

\section{Discussion of Debt-for-Nature Swap Criticism}

\section{The Fear for a Loss of Sovereignty: The Brazilian Case}

Brazil's resistance against a possible debt-for-nature swap is primarily nurtured by a set of ethical, moral and political reasons. 27 The starting point of this line of argument can be traced back to the original responsibility for the debt crisis. One could argue that the Third World countries were sold a bill of goods in the 1970s by Western bankers anxious to recycle 'petrodollars' and by development 'experts' from the North, who now insist that the Third World pays the price for their bad advice.28 Therefore, accepting a debt-for-nature swap today would implicitly legitimize the morally unjustified claims of the Westem creditors. Once again, it is the North - this time through NGOs operating on a world-wide scale - who sets the agenda and decides how resources will be spent and who will spend them.29 Instead, debt forgiveness ought to be the only motive for the North's new approach, leaving all decisions to the people in the South on what to do with the newly available resources.

Containing some $30 \%$ of the world's tropical rain forest and holding almost $10 \%$ of the Third World debt, Brazil seemed to be the prime candidate for a debt-for-nature swap. Nevertheless, in Brazil, as elsewhere in the Third World, the moral hard-liners seemed to have lost out to a more pragmatic approach, and a debt-for-nature swap was seriously under consideration after the Bolivian deal had come through. There was an increasing awareness within the country of the importance of preserving the environment and the global implications of ecological problems. As long as conservation projects were to stay in Brazilian

26 See Schreiber, op. cit., pp. 23-24.

27 For a discussion of the Brazilian case, see James Brooke, Brazil Wants Foreign Aid to Fight Pollution, but No Strings, New York Times, March 31, 1989; Ball, op. cit., pp. 24-27; Barbara Bramble and Brent H. Millikan, Extemal Debt, Democratization, And Natural Resources In Developing Countries: The Case Of Brazil, National Wildlife Federation, Washington, D. C., June 27, 1989.

28 See John Cartwright, Conserving nature, decreasing debt, Third World Quarterly, Vol. 11, No. 2, pp. 115, 123, and 127. Cartwright sympathizes with this point of view without telling the whole story: Third World govemments always had the power to say no.

29 See Carol Barton, Debt Swaps: New Game in Town, Christianity and Crisis, Vol. 48, No. 3, March 7, 1988, pp. 63-64. 
hands, ${ }^{30}$ the country seemed ready to accept outside assistance on the environment. Detailed plans were discussed to raise $\$ 4$ billion and buy discounted Brazilian debt of roughly $\$ 8$ billion face value, sufficient to protect large parts of the remaining rain forest of the Amazon basin.31 In early 1989, however, a visit of three U.S. senators, who apparently overemphasized the case, tumed the tide. 32 Debt-for-nature swaps were no longer under consideration. Brazil's President Samey announced an ambitious environmental program that was to be run and administered by the country without foreign interference, except for the welcome provision of new credits from international organizations for environmental projects. 33 Debt-for-nature swaps were now considered as a retum to the colonial system, whereby Brazil would ultimately lose control over its rich Amazon basin to foreign powers more concerned with the negative impacts on the global climate than with Brazil's overwhelming social and economic problems. 34 These pressing problems require that Brazil seeks to obtain quick short-term financial rewards from the Amazon by issuing timber licences, etc. 35

The surge of nationalistic perceptions on the side of the Samey administration is related to the November elections in Brazil, practically foreclosing any new efforts for a debt-fornature swap until a new government will have taken office in March 1990 - a delay that much of the Amazon basin's fauna and flora is increasingly ill-prepared to grant and that is also deplored by a number of already existing Brazilian NGOs ready to serve as local counterparts in a possible swap.

The case of Brazil illustrates that no matter how well the stage might be set for a debt-fornature swap, political sovereignty, ethical and moral vulnerabilities, and nationalistic feelings have to be taken into account very carefully. In places where the IMF and the World Bank are already imposing tough conditions, anything else that bears the taste of foreign intervention 36 has to operate with utmost precaution and delicacy, no matter how

30 See the February, 1989, statement of Brazil's Secretary General of the Foreign Ministry, Paulo Tarso de Fletch Lima, as quoted in Marlise Simons, Brazil Agrees to Accept Aid to Save Rain Forests, New York Times; February 5, 1989.

31 See Brazil's Debt Can Save the Amazon, New York Times editorial, February 3, 1989.

32 Carlos E. Quintela, Director Brazil and Bolivia Programs, The Nature Conservancy, Arlington, Virginia, Interview on September 13, 1989.

33 See Roger Cohen, Amazon Tug-of-War Reaches Fever Pitch: Rich Nations See It as Vital Resource, Brazil as Economic Boon, Wall Street Journal, April 7, 1989, for details about the Brazilian \$100 million, five-year environmental program "Nossa Natureza".

34 For further references on this see Ball, op. cit., p. 26.

35 However, an important moral argument tends to be easily forgotten: The indigenous people living off the rain forest are bearing the costs of ongoing deforestation policies.

36 It should be clear from the above, however, that in all debt-for-nature swaps so far, the resulting funds are managed by local organizations, and they are structured to meet local conservation priorities. Land purchases by foreigners are never involved. See Bramble and Millikan, op. cit., p. 
justified the cause might be. The case also shows that the major obstacles to the deals are political: Anywhere along the line of complicated three- and more partite negotiations, a misunderstanding or wrong perception about what debt-for-nature swaps are and are not can be turned into a political argument and halt the whole procedure. Good information about the concept seems to be of critical importance.

\section{The "Contamination", Inflation, and Enforcement Issues}

Other arguments against debt-for-nature swaps are forwarded from the other extreme side in the debate over the debt crisis. Those putting the blame solely on incompetent Third World govemments refuse to make any concessions, including swaps. There is also the fear that accepting one such deal might contaminate the rest of the bank's portfolio. 37 This argument, however, seems somewhat paradoxical, because the emergence of secondary markets early in the debt crisis demonstrated that significant debt reduction will eventually have to be accepted. The question is only about when and about the conditions offered and accepted by borrowers and lenders. This, in turn, is already reflected in the flexibility of rates in the secondary market. Even the United States, hitherto among the most adamant of countries opposing serious debt reduction, now appears more ready to acknowledge reality, a new policy which is witnessed by the Brady Plan. Following the lead of European banks, the more exposed U.S. banks have also sharply raised their provisions against Third World debts. 38 Thus, despite some hard-liners grumbling, the time may be not as far away as it used to be for opening debt relief negotiations on a larger scale. Debt-for-nature swaps help to sharpen the view that debt forgiveness ought to benefit the environment.

More constructive criticism focused directly on the deals. As with debt-equity swaps, there is a potential problem of increased inflation caused by the issuance of local currency in exchange for the debt. 39 Although debt-for-nature swaps are reducing the pressure for hard currency eamings, they may contribute to domestic financial disruption. However, as most observers agree, 40 as long as debt-for-nature swaps remain at relatively small scale in the countries involved, the money supply does not increase significantly, if local currency bonds with maturities staggered over the life of the program are issued, as has been the case with most deals. Therefore, the other accusation that debt-for-nature swaps do not solve the debt crisis simply, because they involve only much less than $0.1 \%$ of total outstanding

9, fn. 4. As Ball, op. cit..p. 37, puts it correctly: "The issue is really one of perceived patemalism, not direct foreign control."

37 For a discussion of this argument see Ball, op. cit., pp. 41-42.

38 See The Economist, Vol. 312, No. 7622, September 30, 1989, pp. 96-97.

39 See Hansen, op. cit., p. 15; Oberndörfer, op. cit., pp. 23-24.

40 See SWAPS, op. cit., p. 5, and von Moltke, op. cit., p. 4. 
debt, ${ }^{41}$ can be turned into an argument that reduces inflationist fears. The answer here is, of course, also: Debt-for-nature swaps were never intended to solve the debt crisis and probably never will. They are one of the many ideas put forward to alleviate the crisis. And, as we see it, one that also makes a lot of sense.

Another more important problem refers to the enforcement of the environmental objective of a debt-for-nature swap. 42 Reducing the debt burden slightly and excluding a reserve from economic exploitation are insufficient steps to change the pressures placed on these areas significantly. Besides, the pressure on areas not included in the deal may well increase. As long as the economic fundamentals and the population pressure persist, tropical forests will be in danger. Anyone familiar with local administrative capacity in many LDC countries will doubt that the desirable environmental protection can be enforced.

While this is certainly a weakness of debt-for-nature swaps, these counter-arguments have not been taken lightly. The agreements must include compensation systems 43 that can be terminated if the terms are not adhered to. It is hoped that the LDC government will continue to pay off the bonds out of a well-perceived self-interest: The interest and the principal are invested into the country's future, and defaulting would be looked upon unfavorably by commercial and private lenders. Ultimately, the enforcement depends upon the local NGO that acts as the administrator of the deal. Successfully strengthening the management capacity of local NGOs 44 charged with the projects and reserves will be the key factor in the enforcement issue. It is too early to say whether the existing deals are and will be able to do so, but the alternative - no action on the environment at all - is certainly worse. And, as explained above, "sustainable development" does not necessarily imply a complete set-aside but a sensible use of existing variety without threatening the ecological link.

41 It should also be noted that the billions of dollars that has been invested in debt-equity swaps do not even affect one per cent of the total debt burden.

42 See Cartwright, op. cit., p. 124-125; Hansen, op. cit., p. 6; Alvaro Umana, Costa Rica's Minister for Natural Resources, Energy and Mines, Costa Rica Swaps Debt for Trees, in: Wall Street Journal, March 6, 1987; Wolfgang Jung, Auch wir sind für die Ökokatastrophe in den Tropen verantwortlich, in: Frankfurter Rundschau, January 31, 1989.

43 The importance of compensation while restricting the use of the nature is stressed by Oberndörfer, op. cit., pp. 32-36.

44 The problem might also be one of creating these NGOs in the first place, notably in Africa, whereas in Latin America, there are more than 230 national conservation groups, although some place the number in Brazil alone at 2,000. See Lisa Fernandez, Private Conservation Groups on the Rise in Latin America and the Caribbean, WWF Letter, No. 1, 1989, pp. 1-2. 


\section{Additional Advantages of Debt-for-Nature Swaps: Cooperation, Conservation of Economic Potential, and Decentralization}

Our discussion has already outlined some of the advantages associated with debt-for-nature swaps. They can alleviate a small part of the debt burden, while strengthening local administrative capacity; make funds available that used to be blocked for servicing the debt; and dramatically increase the impact of conservation dollars. 45 In addition, they provide opportunities for cooperation between North and South, for long-term economic advantages in LDCs, and for new ways of decentralized, market-based environmental action.

Debt-for-nature swaps might be able to set the stage for a much more constructive relationship between North and South than during the 1970s, when the debate about a new international economic order ultimately left much of the South worse off than before. There is sharpening awareness, among the public and even among politicians in the North, that stopping the greenhouse effect will involve some definite costs. It is also obvious that LDCs are in need of substantial funds to cope with the debt crisis and promote further development. This new interdependency will require a new form of cooperation, whereby the South has a bargaining power considerably higher than in the past. Debt-for-nature swaps are an initial sign of this era.

Another argument lies with the long-term economic side of the matter. More and more people come to accept the notion that the short-term financial retums of traditional exploitation are outweighed by the long-term costs associated with the inevitable environmental degradation. All depends upon a sufficient compensation for foregoing the immediate benefits of rapid development. Non-traditional ways of exploiting tropical rain forests are increasingly discussed.46 Economists studying the value of forest products in local markets reckon that fruit, nuts and rubber may be worth more than twice as much as the same land logged or tumed into cattle pasture. However, up to now, commercial companies from the North have done virtually nothing to support research about marketable produces of the rain forest. The job of identifying new medicines from the almost untapped genetic reservoirs, of finding aromatic oils and timber, and of showing how they might be sustainably exploited, has been left to an underfinanced handful of primarily local research institutes. Equally depressing, the debate about the greenhouse effect has increased the money spent on complicated computer scenarios about climatic changes without much action on the ongoing tropical deforestation. While the understanding about the long-term

45 See Kathryn S. Fuller and Douglas F. Williamson, Debt-for-Nature Swaps: A New Means of Funding Conservation in Developing Nations, (BNA) Intemational Environment Reporter, November 1988, p. 303.

46 See The Economist, The month Amazonia bums, and Rain-forest products, Growing profits, Vol. 312, No. 7619, September 9, 1989. 
value of intact biological reserves - particularly tropical rain forests - has sharpened, nothing much is done to stop the ongoing traditional exploitation. This is where debt-fornature swaps really make a difference. They do not foreclose the future economic returns from the reserves. With the projects involved in the deals, they make valuable contributions to a better understanding of how to combine short and long-term economic use of ecological systems without having the local population carry the burden. On the contrary, the deals provide new jobs and opportunities for those people who know their traditional habitat best or for those who are now presented with a worthwhile alternative to traditional exploitation.

While global plans have been discussed for years without much of an impact on the environment, debt-for-nature swaps are an existing practical way to act now. We do not underestimate the difficulties and transaction costs in negotiating and implementing these deals, however they can be set up without building up new large international organizations and huge governmental bureaucracies. 47 Most of the work to establish these agreements has been done by NGOs which - by definition - have a strong incentive to protect and supervise specific areas. The individual contributor to an NGO can therefore identify the details of spending. Donations could probably be forthcoming a lot easier, if the debt-fornature swap option was used more often. Financing environmental protection in the Third World, this way, could improve.

\section{Outlook and Recommendations}

With a whole list of arguments in their favor, debt-for-nature swaps seem likely to play a more prominent role in the future. However, the state of information about the usefulness of this concept is insufficiently developed in both the South and the North. At this point, a note of caution is necessary for a realistic image of the dimensions of the issue: Debt-fornature swaps will not solve the debt crisis, but they will help to explore one option that outlines a sensible way to be followed. As long as the desirable, comprehensive debt reduction and/or forgiveness does not proceed, which, under today's conditions, is neither likely nor easily feasible, debt-for-nature swaps will be a workable and already existing tool to help the environment, albeit on a limited scale.

Debt-for-nature swaps have emerged in the U.S American setting and have just started to be applied elsewhere. At the same time, the knowledge and understanding of this concept is

47 For an example of these global plans, see the ecological "Marshall-plan" put forward by Lutz Wicke, Klotzen, nicht kleckem. Ein ökologischer Marshallplan für den Tropenwald könnte den Industrieländem selbst helfen, Die Zeit, Oktober 1989, p. 36. To stress the point: The present authors would welcome an intemational solution to the issue, but do, unfortunately, not see it realized fast enough. 
underdeveloped within West Germany. This gives rise to the following four recommendations:

1) Environmental protection groups should consider to become a party to a debt-for-nature swap agreement.

2) Since German banks are less exposed to troubled Third World debts and because they have already written off the major share of them, they could get involved in debt-fornature swaps much easier than American banks. Therefore, German banks should donate a larger part of the debts and raise awareness among their clients in the business world about these new opportunities for donation.

3) Through its various development agencies, the German govemment should reduce the transaction costs of negotiating debt-for-nature swaps. For example, the agencies could establish a data base or a clearing house for information that would include listings of environmental projects in need of funding and other parties interested in participating. Research could also be done to evaluate existing projects. Furthermore, the government should investigate careful approaches to forgiving of public debts in a manner that does not arouse the concern of LDC govemments about their sovereignty.

4) A sensible way to start would be to bring together all possible German participants interested in future deals. The church or other well-respected organizations could act as a mediator in initiating round table discussions of this type. Given the relatively small size of a debt-for-nature swap, initial projects could also be worked out on a regional or even local level. 
approach to conservation, as opposed to sustainable development, combined with the economic incentives both for debt and debtor countries.

\section{Debt-for-Nature Swaps: Environmental Colonialism or a Way Out from the Debt Crisis that Makes Sense?}

\section{By Hildegard Bedarff, Bernd Holznagel, and Cord Jakobeit}

The paper describes the mechanism of debt-for-nature swaps and illustrates this new concept by presenting the most interesting cases which have been initiated so far. In one case, the authors give insight into the detailed arrangement. Finally the pros and cons of debt-for-nature swaps are discussed in the light of the future prospects of this innovative way to finance environmental protection in the Third World.

It is argued that these swaps are neither environmental colonialism nor a way to solve the debt crisis. However, as it is pointed out, they are a creative way to alleviate a small part of the Third World debt while saving much-needed funds for the fight against environmental degradation in many Third World countries - degradation that is closely tied to the emergence of the debt crisis itself. Whereas a comprehensive debt reduction and/or forgiveness would be more effective and desirable for the environment, it is, under today's conditions, neither likely nor easily feasible. Debt-for-nature swaps, in turn, are a workable and already existing way to help the environment, albeit on a small scale.

Considering the West German perspective, the article concludes with four recommendations for policy-makers, bankers and the public.

\section{Environmental Degradation and the Law in Tanzania}

\section{By Costa R. Mahalu}

The article gives an insight into the state of environmental degradation from a factual and a legal point of view. On the factual side, the author covers the effects of pollution on the Tanzanian land, marine and air environment. 